\title{
A Comparative Analysis of Covid-19 Cases and Deaths in Different Continents of the World
}

\author{
Sabina Khanam* \\ Department of Biological Sciences, Yobe State University, Nigeria \\ *Corresponding author: Sabina Khanam, Department of Biological Sciences, Yobe State University, Nigeria
}

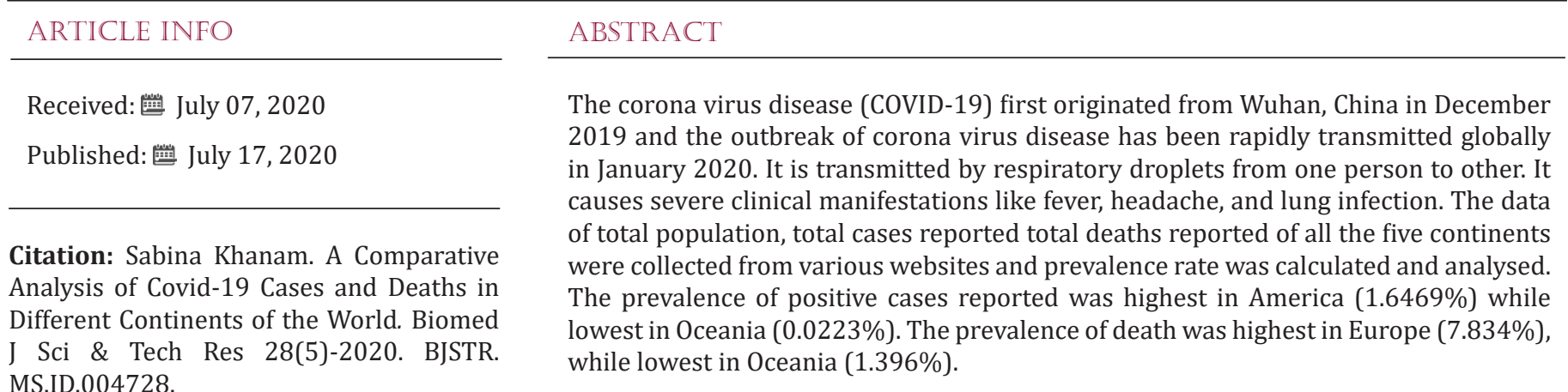

Keywords: COVID-19; Prevalence; World

\section{Introduction}

Coronavirus belongs to a family called virus with single stranded RNA as genetic material. Several genetic studies revealed that it was a SARS-like virus. International Committee on Taxonomy of Viruses named it SARS-CoV-2 and World Health Organization named the disease caused by this virus was COVID-19. This virus binds to the angiotensin-converting enzyme 2 (ACE2) receptor by using a densely glycosylated spike protein to enter in the host cells in humans. Due to ACE2 receptor COVID-19 patient show upper and lower respiratory tract infection because ACE2 is typically expressed in type II alveolar cells in the lungs Gorbalenya, et al. $[1,2]$. The outbreak of novel coronavirus disease (COVID-19) has been rapidly transmitted globally in January 2020. It is originally originated from Wuhan, China in December 2019. It is transmitted via respiratory droplets and it more common in elderly persons. It causes many severe clinical manifestations such as pneumonia, dry cough, fatigue, fever, headache, abdominal pain, diarrhea, lung infection and difficulty in breathing. This novel coronavirus causes pneumonia and affect the lower respiratory tract of infected person. Researchers studied on this virus and identified this virus as severe acute respiratory coronavirus and named severe acute respiratory syndrome coronavirus 2 (SARS-CoV-2) Sohrabi, et al. [3-8].

\section{Material and Method}

This research was carried out on $2^{\text {nd }}$ July 2020. The major objective of this study was to examine and compare COVID-19 cases and death prevalence of different continents of the world.

\section{Data Collection and Analysis}

The data of total population, total cases reported, total deaths reported of all the five continents Africa, Asia, America, Europe and Oceania were collected from various websites and prevalence rate was calculated by using the formula given below:

$$
\text { Prevalence rate }=\begin{aligned}
& \overline{\text { No. of Patient's having malaria }} \\
& \text { Total No. of Patient's diagnose }
\end{aligned} \times 100
$$

\section{Statistical Analysis}

Data analysis was done by using SPSS. Variables were presented in frequencies and percentages, and distributed continuous variables were presented as mean and standard error of mean (SEM).

\section{Results and Discussion}

(Table 1) presents the continent wise prevalence rate of corona cases and death rate worldwide. A total of 1,06,65,758 
positive cases reported in all the continents of the world, which is $0.1501 \%$ of the total population $(7,10,30,93,422)$ of all the continents as at $2^{\text {nd }}$ July 2020. Out of total positive cases a total of 5451474 (1.6469\%) people out of 33,10,02,651total population were positive in America, which was highest in all the continents, while lowest in Oceania around 9522 (0.0223\%) people, out of $4,26,77,259$ total population were positive to corona. In Africa, Asia and Europe the prevalence rate was $0.0312 \%$ (418314), $0.0501 \%$ (2328919) and $0.3287 \%$ (2457529) respectively. A total of $5,15,973(4.837 \%)\left(\mathrm{p}=0303^{*}\right)$ deaths reported worldwide out of total $1,06,65,758$ positive cases, in which $7.834 \%(192539)$ deaths reported in Europe which highest in all the continents, while $1.396 \%$ (133) deaths reported in Oceania which is lowest in all the continents. In Africa, Asia, and America the death rate was $2.486 \%$ (10400), 2.460\% (57302), and 4.688\% (255599) respectively. Hsu, et al. [9] reported 8565 confirmed positive cases and 132 deaths in 67 territories outside mainland China on 2nd of March 2020. As on 31st March 2020, WHO reported 693,224 total positive cases globally and 33,106 deaths globally in which 103,775 cases and 3649 deaths belongs to Western Pacific Region, 392,757 cases and 29,962 deaths in European Region, 4084 cases and 158 deaths in South East Asia Region, 46,329 cases and 2813 deaths in Eastern Mediterranean Region, 142,081 cases and 2457 deaths In Regions of America and 3486 cases and 60 deaths in Africa Region WHO, [10].

Table 1: Continent wise Prevalence rate of Corona cases and Death rate worldwide as at $2^{\text {nd }}$ July 2020.

\begin{tabular}{|c|c|c|c|c|c|}
\hline Continent & Total Population & Total Cases Reported & $\begin{array}{c}\text { Prevalence rate of } \\
\text { Reported Cases (\%) }\end{array}$ & Deaths Reported & $\begin{array}{c}\text { Prevalence Rate of } \\
\text { Death Reported (\%) }\end{array}$ \\
\hline Africa & $1,34,03,77,318$ & 418314 & 0.0312 & 10400 & 2.486 \\
\hline Asia & $4,64,14,00,305$ & 2328919 & 0.0501 & 57302 & 2.460 \\
\hline America & $33,10,02,651$ & 5451474 & 1.6469 & 255599 & 4.688 \\
\hline Europe & $74,76,35,889$ & 2457529 & 0.3287 & 192539 & 7.834 \\
\hline Oceania & $4,26,77,259$ & 9522 & 0.0223 & 133 & 1.396 \\
\hline Total & $7,10,30,93,422$ & $1,06,65,758$ & 0.1501 & $5,15,973$ & 4.837 \\
\hline $\begin{array}{c}\text { Mean } \pm \text { SEM } \\
\mathrm{p}\end{array}$ & & $\begin{array}{c}2133151.5 \pm 964501.94 \\
0.0914 \mathrm{NS}\end{array}$ & $\begin{array}{c}0.415 \pm 0.313 \\
0.2547 \mathrm{NS}\end{array}$ & $\begin{array}{c}103194.6 \pm 51258.95 \\
0.1143 \mathrm{NS}\end{array}$ & $\begin{array}{c}3.772 \pm 1.148 \\
0.0303^{*}\end{array}$ \\
\hline
\end{tabular}

Source: Total Cases and deaths www.ecdc.europa.eu

\section{References}

1. Gorbalenya AE, Baker SC, Baric RS, De Groot R, Drosten C, et al. (2020) The species severe acute respiratory syndrome-related coronavirus: classifying 2019-nCoV and naming it SARS-CoV-2. Nat Microbiol 5(4): 536-544.

2. Del Rio C, Malani PN (2020) COVID-19- new insights on a rapidly changing epidemic. JAMA 323(14): 1339-1340.

3. Sohrabi C, Alsafi Z, O' Neill N, Khan M, Kerwan A, et al. (2020) World Health Organization declares global emergency: a review of the 2019 Novel Coronavirus (COVID-10). Int J Surg 76: 71-76.

4. (2020) WMHC. Wuhan Municipal Health and Health Commission's Briefing on the Current Pneumonia Epidemic Situation in Our City.

5. Lu H, Stratton CW, Tang YW (2020) Outbreak of pneumonia of unknown ethology in Wuhan, China: The mystery and miracle. Journal of virology 92(4): 401-402.

ISSN: 2574-1241

DOI: 10.26717/BJSTR.2020.28.004728

Sabina Khanam. Biomed J Sci \& Tech Res

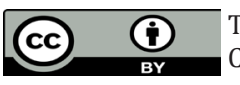

This work is licensed under Creative Commons Attribution 4.0 License

Submission Link: https://biomedres.us/submit-manuscript.php
6. Li Q, Guan X, Wu P, Wang X, Zhou L, et al. (2020) Early transmission dynamics in Wuhan, China of novel coronavirus-infected pneumonia. N Engl J Med 382: 1199-1207.

7. Lai CC, Shih TP, Ko WC, Tang HJ, Hsueh PR (2020) Severe acute respiratory syndrome coronavirus 2 (SARS-CoV-2) and coronavirus disease-2019 (COVID-19): The epidemic and the challenges. Int J Antimicrobial Agents 55(3): 105924.

8. (2020) World Health Organisation. Novel Coronavirus-China.

9. Hsu LY, Chia PY, Lim JF (2020) The Novel coronavirus (SARS-CoV-2) epidemic. Ann Acad Med Singap 49: 105-107.

10. (2020) World Health Organisation Coronavirus Disease 2019 Situation Report 70.

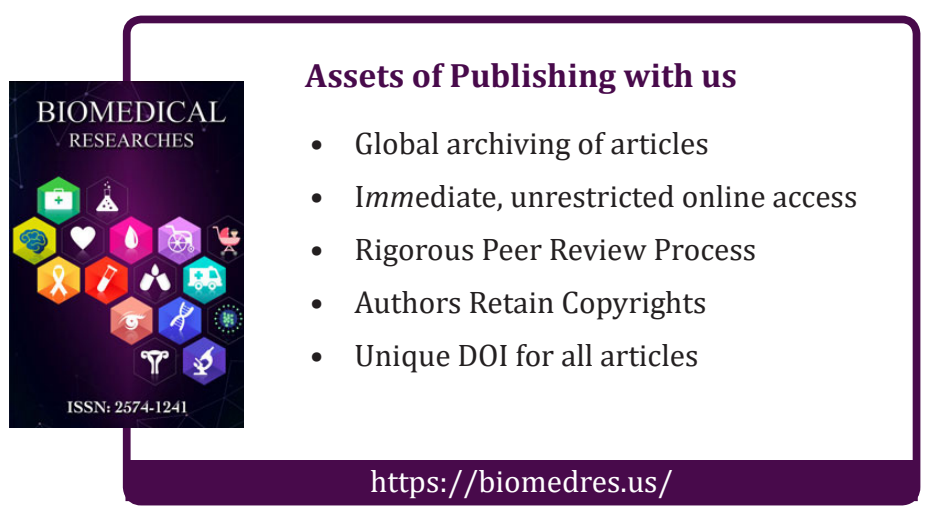

Copyright@ Sabina Khanam | Biomed J Sci \& Tech Res | BJSTR. MS.ID.004728. 